\title{
PENGARUH MOTIVASI BELAJAR SISWA TERHADAP KEMAMPUAN BERPIKIR KREATIF IPA PADA MATERI SIKLUS AIR KELAS V DI SDN 2 SENGONBUGEL
}

\author{
Lutfiya Laily Agustin ${ }^{1 *}$ \\ Fina Fakhriyah ${ }^{2}$ \\ Ika Ari Pratiwi ${ }^{3}$ \\ 1,2,3Prodi Pendidikan Guru Sekolah Dasar, Universitas Muria Kudus, Indonesia \\ lelylutfia1@gmail.com ${ }^{1 *}$ \\ fina.fakhriyah@umk.ac.id ${ }^{2}$ \\ ika.ari@umk.ac.id ${ }^{1}$
}

\begin{abstract}
Abstrak
Penelitian ini merupakan penelitian kuantitatif dengan metode survey deskriptif yang bertujuan untuk mengetahui pengaruh antara motivasi belajar terhadap kemampuan berpikir kreatif IPA siswa Kelas V di SDN 2 Sengonbugel. Populasi dalam penelitian ini adalah siswa kelas V SDN 2 Sengonbugel yang berjumlah 20 siswa yang terdiri dari 12 siswa laki-laki dan 8 siswa perempuan. Penelitian ini melalui tes sebanyak 2 kali yaitu pre-test dan post-test untuk mengetahui kemampuan berpikir kreatif siswa pada pembelajaran IPA. Pengambilan sampel dilakukan dengan teknik purposive sampling. Variabel penelitian terdiri dari variabel bebas yaitu motivasi belajar, sedangkan variabel terikatnya yaitu kemampuan berpikir kreatif. Pengujian hipotesis menggunakan progam SPPS versi 25. Hasil penelitian Motivasi belajar berpengaruh secara positif dan signifikan terhadap kemampuan berpikir kreatif siswa kelas V SD N 2 Sengonbugel. Hal ini menunjukkan bahwa Motivasi belajar memberikan kontribusi terhadap kemampuan berpikir kreatif sebesar 33,4\% sedangkan sisanya $(100 \%-33,4 \%=66,6 \%)$ dipengaruhi oleh variabel lain diluar penelitian.
\end{abstract}

Kata Kunci: Motivasi Belajar, Kemampuan Berpikir Kreatif, Pembelajaran IPA.

Published by:

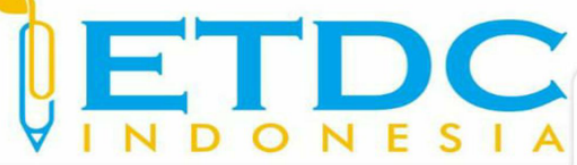

Copyright (C) 2021 The Author (s)

This article is licensed under CC BY 4.0 License

(cc) $\mathrm{BY}$ 


\section{PENGARUH MOTIVASI BELAJAR SISWA TERHADAP KEMAMPUAN BERPIKIR KREATIF IPA PADA MATERI SIKLUS AIR KELAS V DI SDN 2 SENGONBUGEL}

\section{Pendahuluan}

Pendidikan merupakan sarana terpenting dalam meningkatkan kualitas dalam memberikan pengajaran tentang perkembangan individu, oleh karena itu sekolah mempunyai peran penting dalam membimbing siswa agar mampu mencapai tingkat perkembangan melalui pemenuhan tugas perkembangan secara ideal. Secara formal pendidikan dilaksanakan sejak usia dini hingga jenjang perguruan tinggi, namun pada hakikatnya pendidikan akan berlangsung sepanjang hayat sejak lahir hingga dewasa. Pendidikan berasal dari bahasa Yunani yang dapat diterjemahkan sebagai bentuk membimbing dan memimpin. Selanjutnya pendidikan diartikan sebagai kegiatan untuk meningkatkan sikap dan perilaku yang dilakukan dan dilakukan untuk mencapai tujuan tertentu.

Seiring dengan perkembangan ilmu pengetahuan dan teknologi saat ini, pendidikan dituntut untuk maju. Salah satu cara untuk meningkatkan mutu pendidikan nasional adalah melalui metode belajar mengajar yang diterapkan di sekolah. Melalui metode ini diharapkan dapat menumbuhkan sikap dan perilaku yang kreatif dan inovatif kepada siswa. Pendidikan nasional perlu diselenggarakan secara terpadu dan sesuai dengan perkembangan ilmu pengetahuan dan kemajuan teknologi. Kemampuan berpikir kreatif dewasa ini sangat dibutuhkan oleh seseorang dalam menghadapi kemajuan dan perkembangan zaman. Peraturan Menteri Pendidikan Nasional Nomor 23 Tahun 2016 menyatakan bahwa standar kompetensi kelompok mata pelajaran IPA dan teknologi pada tingkat sekolah dasar bertujuan untuk mengembangkan dan menerapkan informasi, pengetahuan, dan teknologi secara logis, kritis, kreatif, dan secara mandiri. Pada kenyataannya banyak siswa yang memiliki kemampuan berpikir kreatif tetapi sulit untuk diketahui sehingga pemikiran kreatif yang menarik menjadi masalah di kalangan peneliti.

Pembelajaran tematik dapat mengembangkan keaktifan siswa dalam menggali dan menemukan konsep yang bermakna dalam ranah kognitif, afektif, dan psikomotorik. Dalam mengimplementasikan kurikulum 2013, guru dibimbing untuk berkreasi dan menciptakan kegiatan belajar mengajar sesuai dengan rumusan kurikulum serta didukung dengan berbagai metode dan media pembelajaran yang sesuai dengan kondisi sekolah. Dalam penelitian ini, peneliti hanya fokus pada mata pelajaran IPA.

Susanto (2016) menjelaskan dua aspek akan tercapai jika guru membangun kemampuan 
kreativitas siswa. Kreativitas yang tinggi maka potensi dan keterampilan siswa akan berkembang. Satu tujuan dari pendidikan sebagai sarana prasana untuk mengembangkan potensi dan kemampuan agar menjadi anak yang kreatif. Potensi yang harus dikembangkan untuk menghadapi perkembangan pada zaman sekarang hanya kecerdasan melainkan juga kreativitas siswa. Satu tujuan dari pendidikan yang disebutkan diatas adalah untuk mengembangkan potensi siswa agar dapat menjadi anak yang kreatif atau memiliki kreativitas yang tinggi. Susanto (2016) menjelaskan kreativitas adalah kemampuan mengungkapkan hubungan- hubungan baru, melihat sesuatu dari sudut pandang baru dan membentuk kombinasi baru dari dua konsep atau lebih yang dikuasai sebelumnya, maka berpikir kreatif dapat dimaknai dengan berpikir yang dapat menghubungkan atau melihat sesuatu dari sudut pandang baru. Kemampuan berpikir kreatif tidak hanya untuk menghasilkan ide atau gagasan baru melainkan menghasilkan banyak pemecahan dan mengatasi sebuah permasalahan. Kemampuan berpikir kreatif dibutuhkan oleh manusia dalam menghadapi perkembangan dan kemajuan zaman pada saat ini. Perkembangan teknologi dan informasi pada saat ini tidak dapat dipungkiri, kemampuan manusia untuk berpikir kreatif dibekali akal, budi, dan karsa menciptakan perubahan-perubahan pengetahuan yang ada dan mengimplementasi untuk memecahkan masalah-masalah yang dihadapi pada masa pandemi.

Pemerintah di Indonesia telah menanamkan kebijakan untuk mengatasi masalah pemberlakuan social separating kepada seluruh lapisan masyarakat. Tidak hanya itu, PSBB (Pembatasan Sosial Berskala Besar) juga diberlakukan di beberapa kota besar di Indonesia. Kebijakan ini telah tertuang dalam PP Nomor 21 Tahun 2020. Kebijakan tersebut dilaksanakan untuk memutus mata rantai penyebaran Covid-19. Pemerintah telah menetapkan kebijakan belajar dari rumah atau biasa disingkat BDR melalui Surat Edaran Menteri Pendidikan dan Kebudayaan Nomor 36962/MPK.A/HK/2020 yang berisi bahwa belajar harus dilakukan dari jarak jauh agar Virus Corona Penyakit (Covid-19) dapat dicegah penyebarannya melalui pembelajaran jarak jauh. jauh dan diimplementasikan untuk memberikan pengalaman belajar. Hal ini berdampak pada berbagai kegiatan termasuk terbatasnya kegiatan belajar mengajar. Seiring dengan perkembangan ilmu pengetahuan dan teknologi, sangat memungkinkan bagi setiap individu untuk memiliki kemampuan berpikir kreatif agar mampu memilih dan mengolah informasi perkembangan terkini.

Guru memiliki peran yang sangat penting untuk menentukan kualitas pembelajaran yang dilaksanakan. Guru menjadi komponen yang menentukan hasil atau tidaknya pendidikan tersebut. Pembelajaran IPA merupakan pembelajaran yang berdasarkan pada prinsip-prinsip, proses yang dapat menumbuhkan sikap ilmiah siswa terhadap konsep-konsep IPA. 
Pembelajaran IPA di Sekolah Dasar dilakukan dengan penyelidikan sederhana dan bukan hafalan terhadap kumpulan konsep IPA. Kumala (2016) mengemukakan bahwa "Ilmu pengetahuan alam membahas gejala-gejala alam yang disusun secara sistematis yang didasarkan pada hasil percobaan dan pengamatan yang dilakukan oleh manusia. Berdasarkan pengertian tersebut pembelajaran IPA bukan sekedar ilmu pengetahuan yang mempelajari teori dan gejala alam semata melainkan juga ilmu yang digunakan untuk mengembangkan banyak ide bervariasi yang sebelumnya tidak ada, serta meningkatkan kemampuan berpikir kreatif.

Kenyatannya pada pernyelesaian soal pelajaran IPA siswa masih mengalami kesulitan mengembangkan kemampuan berpikir kreatif selama menyelesaikan soal pada pelajaran IPA. Berdasarkan hasil observasi pada September 2020, pada saat pembelajaran daring di SDN 2 Sengon Bugel diperoleh informasi dari siswa kelas V yang tergolong kemampuan berpikir kreatif yang rendah. Hal tersebut terlihat dari siswa menghasilkan gagasan yang beragam dan ketidakmampuan antar siswa untuk bertukar pendapat. Kondisi tersebut terjadi karena Proses pembelajaran yang digunakan secara daring oleh guru, namun hanya beberapa siswa yang aktif bertanya. Hal tersebut membuat motivasi belajar siswa rendah, karena dilakukan secara online. Serta kurangnya pendampingan orang tua selama pembelajaran dirumah akibatnya siswa merasa kebingungan dalam bertanya dan menyelesaikan soal yang diberikan guru selama pembelajaran daring.

Peneliti juga memperoleh information nilai hasil belajar siswa pada mata pelajaran IPA yang diperoleh dari master kelas V yang berjumlah 20 siswa di SDN 2 Sengonbugel menunjukkan masih ada siswa yang belum mencapai KKM. Berdasarkan information tahun ajaran 2019/2020 yang diperoleh pada daftar mata pelajaran IPA kelas V ditentukan nilai KKM yaitu hasil observasi pretest di SDN 2 Sengonbugel, pada tanggal 27 November 2020 hasil belajar siswa menunjukkan bahwa hasil diperoleh rata-rata 70 dan tuntas klasikal 45\%, sehingga belum tuntas sesuai KKM. Dari information hasil belajar menunjukkan perlunya kemampuan berpikir kreatif siswa untuk mengetahui tingkat berpikir kreatif siswa. Setiap siswa memiliki tingkat kreativitas yang berbeda, perbedaan tersebut dapat mempengaruhi hasil belajar IPA. Selanjutnya, perbedaan kemampuan berpikir kreatif dalam pembelajaran IPA akan disesuaikan dengan kemampuan tingkat berpikir siswa. Tentunya hal ini berdampak pada pola pikir siswa yang akan mengalami kesulitan dalam memecahkan masalah dalam pembelajaran khususnya dalam pembelajaran tematik siswa dituntut untuk kreatif dan aktif dalam pembelajaran di sekolah dasar.

Siswa kreatif dalam berpikir untuk memecahkan masalah merupakan salah satu tujuan yang harus dicapai dari mata pelajaran IPA. Ramadhani dan Nuryanis (2017) mengungkapkan 
bahwa berpikir kreatif merupakan pemikiran yang bersifat keaslian dan relektif dan menghasilkan suatu produk yang komplek dalam permasalahan IPA. Berpikir tersebut merupakan ide-ide baru dan menentukkan efektivitas. Yuliani dkk (2017) mengemukakan indikator berpikir kreatif yaitu 1) Kemampuan berpikir lancar (fluency), mengajukan banyak pertanyaan, kemampuan mengemukakan ide-ide yang serupa untuk memecahkan suatu masalah, 2) Kemampuan berpikir luwes (flexibility), memberikan bermacam-macam penafsiran (interpretasi) terhadap suatu masalah. 3) Kemampuan berpikir orisinil (originality), memberikan bermacam-macam penafsiran (interpretasi) terhadap suatu masalah, 4) Kemampuan merinci (elaboration), mengembangkan atau memperkaya gagasan orang lain.

Teori diatas dapat disimpulkan bahwa, berpikir kreatif sangat penting dalam proses pembelajaran karena dengan berpikir kreatif dapat menumbuhkan kondisi dalam berlansungnya proses pembelajaran, serta adanya ide yang dapat ditemukan untuk memecakan masalah yang diberikan guru. Tanpa adanya kemampuan berpikir kreatif maka pembelajaran di sekolah dasar tidak berjalan dengan baik. Hal ini merupakan salah satu ciri bawa proses pembelajaran dikatakan tercapai.

Selain itu penelitian serupa yang dilakukan oleh Tina (2020) mengenai pengaruh motivasi belajar siswa terhadap berpikir kreatif pada mata materi aplikasi operasi himpunan kelas VII SMP Muhammadiyah Ambon. Hasil penelitian menunjukkan bahwa tes dan angket yang telah diisi siswa dan diolah peneliti untuk mencari hasil uji t dan diketahui thitung $=2,656$ dikonsultasikan pada $\mathrm{t}$ tabel dengan $\mathrm{n}=28$ dengan taraf signifikan $5 \%$ harga $\mathrm{t}$ tabel $=1,701$. Hal ini menunjukkan bahwa harga t hitung lebih besar dari t tabel $(2,656>1,701)$ sehingga hipotesis diterima. Hasil Regresi Linear sederhana dikatakan berarti menunjukkan bahwa terdapat pengaruh motivasi belajar siswa terhadap berpikir kreatif. Hal ini menunjukkan besar pengaruh 40\% sedangkan sisanya 60\% dipengaruhi oleh variabel lain yang tidak diteliti.

Berdasarkan latar belakang masalah yang telah diuraikan diatas, maka Peneliti tertarik melakukan kajian lebih mendalam permasalahan tersebut pada kelas V SDN 2 Sengonbugel dengan melakukan penelitian yang berjudul "Pengaruh Motivasi Belajar Siswa terhadap kemampuan berpikir kreatif IPA pada materi siklus air kelas V di SDN 2 Sengonbugel”.

\section{Metode Penelitian}

Penelitian ini akan dilakukan dengan menggunakan penelitian kuantitatif dengan metode survei deskriptif. Sugiyono (2016) menyatakan bahwa metode adalah survei yang digunakan untuk memperoleh information dari suatu populasi tertentu yang bersifat alamiah, tetapi penelitian mengumpulkan information dengan cara menyebarkan kuesioner dimana 
peneliti tidak memberikan perlakuan seperti pada percobaan. Teknik pengambilan sampel umumnya dilakukan secara acak, analisis datanya bersifat statistik dengan tujuan untuk menguji hipotesis yang telah ditetapkan. Peneliti bermaksud untuk mengetahui keadaan suatu kelompok tanpa adanya perlakuan apapun. Tujuannya untuk mengetahui ada tidaknya pengaruh motivasi siswa terhadap keterampilan berpikir kreatif.

Populasi dalam penelitian ini adalah seluruh siswa kelas V di SDN 2 Sengonbugel. Sedangkan sampel dalam penelitian ini adalah siswa kelas $\mathrm{V}$ yang berjumlah 20 siswa yang terdiri dari 12 siswa laki-laki dan 8 siswa perempuan di SDN 2 Sengonbugel. Pengambilan sampel dilakukan dengan Teknik purposive sampling yaitu teknik sampling yang digunakan oleh peneliti jika peneliti mempunyai pertimbangan-pertimbangan tertentu dalam mengambil sampelnya. Alasan digunakannya teknik purposive sampling karena kondisi covid-19 saat ini belum bisa melakukan penelitian secara langsung. Variabel penelitian terdiri dari variabel bebas yaitu motivasi belajar, sedangkan variabel terikatnya yaitu kemampuan berpikir kreatif.

Pada penelitian ini, teknik pengumpulan data yang digunakan dalam penelitian ini yaitu tes kemampuan berpikir kreatif dan kuesioner/ Angket motiasi belajar. Bentuk tes kemampuan berpikir kreatif dibuat berupa tes tertulis atau essay yang terdiri dari 7 soal berdasarkan kemampuan berpikir Lancar (fluency), Berpikir luwes (flexibility), Keaslian (Originality), Kerincian (elaboration). Sebelum tes berpikir kreatif di validasi terlebih dahulu oleh dosen penguji.

Instrumen yang diuji dalam penelitian ini adalah validasi, reliabilitas, tingkat kesukaran, dan daya pembeda. Data yang digunakan dalam penelitian yaitu pre-test dan post-tes, pemberian tes berpikir kreatif dilakukan sebanyak dua kali di kelas V. Tes pertama (pre-test) sebelum memberikan materi pembelajaran dan tes kedua (post-test) dilakukan sesudah memberikan materi pembelajaran. Analisis data menggunakan SPSS versi 25.0. Teknik analisis data dilakukan dengan uji analisis statistik deskriptif, uji asumsi dasar, dan analisis akhir (pengujian hipotesis) dalam penelitian ini yaitu menggunakan analisis korelasi sederhana, analisis regresi linier sederhana dan uji independent sample T-test.

\section{Hasil dan Pembahasan}

Penelitian ini akan menggunakan metode deskriptif kuantitatif, karena dalam penelitian ini peneliti melakukan penelitian dengan menyebarkan angket dan soal uraian berpikir kreatif tentang keterampilan berpikir kreatif untuk memperoleh informasi dari responden tanpa ada perlakuan apapun. Penelitian ini berlokasi di SD N 2 Sengonbugel dengan menggunakan sampel seluruh siswa kelas V yang berjumlah 20 siswa. Siswa tersebut terdiri dari 12 siswa 
laki-laki dan 8 siswa perempuan. Uji analisis dalam penelitian ini adalah analisis statistik deskriptif, uji asumsi dasar, dan Hasil Analisis Akhir (Uji Hipotesis).

Posttest dilakukan dengan memberikan pertanyaan kepada siswa. Soal yang diberikan adalah soal yang berkaitan dengan materi pembelajaran IPA siklus air. Posttest dilakukan untuk mengetahui sejauh mana kemampuan berpikir kreatif siswa. Information hasil berpikir kreatif diperoleh dari tes tertulis (essay) sebanyak 7 soal dengan materi siklus air. Berikut hasil analisis statistik deskriptif berpikir kreatif siswa pada posttest kelas V di SD N 2 Sengonbugel disajikan pada Tabel 1 di bawah ini.

Tabel 1. Hasil Analisis Statistik Deskriptif Berpikir Kreatif pretest dan postest

\begin{tabular}{ccc}
\hline Statistik & Nilai Postest & Nilai Postest \\
\hline Jumlah nilai & 1429 & 1771 \\
Jumlah sampel & 20 & 20 \\
Nilai Klasikal & $45 \%$ & $90 \%$ \\
Nilai maksimum & 95 & 100 \\
Nilai minimum & 50 & 61 \\
\hline
\end{tabular}

Berdasarkan hasil perhitungan tersebut, dapat diketahui nilai rata-rata postest adalah sebesar 90. Nilai tersebut termasuk dalam kisaran 90\% - 100\%, artinya kemampuan berpikir kreatif IPA pada materi siklus air siswa kelas V SD N 2 Sengonbugel termasuk dalam kriteria sangat kreatif. Maka untuk menentukan realibilitas soal berpikir kreatif dapat dijelaskan pada Tabel 2. dibawah ini:

Tabel 2. Hasil Uji Reliabilitas Soal Tes Kemampuan Berpikir Kreatif

\begin{tabular}{cccc}
\hline Soal & Koefisien Reliabilitas & r-tabel & Kesimpulan \\
\hline Pretest & 0,929 & 0,443 & Reliabel \\
Posttest & 0,858 & & Reliabel
\end{tabular}

Sumber: Data primer yang diolah, 2021

Berdasarkan Tabel 2. di atas, dapat diketahui bahwa nilai koefisien reliabilitas soal pretest dan posttest kemampuan berpikir kreatif IPA materi siklus air lebih besar dari nilai $\mathrm{r}$ tabel $(0,929$ dan $0,858>0,443)$. Dapat disimpulkan bahwa instrumen soal tes kemampuan berpikir kreatif IPA pada materi siklus air dapat dikatakan reliabel dan memiliki keajegan atau konsisten dalam mengukur kemampuan berpikir kreatif siswa.

Arikunto (2013) mengungkapkan bahwa Hasil uji taraf kesukaran tes soal yang baik dalam menentukan tingkat kesukaran tes adalah soal yang tidak terlalu mudah dan soal yang tidak terlalu sukar. Kriteria berdasarkan ketentuan taraf kesukaran dengan ketentuan yaitu 0,00- 
0,30 (soal sukar), 0,30-0,70 (soal sedang), 0,70-1,00 (soal mudah). Berdasarkan kriteria tersebut, data yang diperoleh kemudian diolah dengan hasil sebagai berikut.

Tabel 3. Hasil Uji Taraf Kesukaran Soal Tes Kemampuan Berpikir Kreatif

\begin{tabular}{cccc}
\hline \multicolumn{1}{c}{ Pretest } & Posttest \\
\hline $\begin{array}{c}\text { Indeks } \\
\text { Kesukaran }\end{array}$ & $\begin{array}{c}\text { Taraf } \\
\text { Kesukaran }\end{array}$ & $\begin{array}{c}\text { Indeks } \\
\text { Kesukaran }\end{array}$ & $\begin{array}{c}\text { Taraf } \\
\text { Kesukaran }\end{array}$ \\
\hline 0,950 & Mudah & 0,875 & Mudah \\
0,900 & Mudah & 0,887 & Mudah \\
0,900 & Mudah & 0,887 & Mudah \\
0,888 & Mudah & 0,900 & Mudah \\
0,938 & Mudah & 0,937 & Mudah \\
0,925 & Mudah & 0,887 & Mudah \\
0,900 & Mudah & 0,887 & Mudah \\
\hline
\end{tabular}

Sumber: Data primer yang diolah, 2021

Berdasarkan Tabel 4.6, dapat diketahui bahwa indeks kesukaran semua soal pretest dan posttest berada pada kisaran 0,70 - 1,00. Jadi, dapat disimpulkan bahwa semua butir soal prestest dan soal posttest termasuk dalam taraf kesukaran mudah.

Analisis statistik inferensial pada penelitian ini, dilakukan beberapa pengujian yaitu uji normalitas, uji linearitas dan uji homogenitas. Ketiga pengujian ini menggunakan aplikasi SPSS Versi 25.0. Hasil pengujian tersebut dapat dilihat pada tabel dibawah ini:

Tabel 4. Hasil Analisis statistik inferensial

\begin{tabular}{llc}
\hline $\begin{array}{c}\text { Analisis Statistik } \\
\text { Inferensial }\end{array}$ & \multicolumn{1}{c}{ Teknik Pengujian } & Signifikansi \\
\hline Uji normalitas & One sample kolmogrov-smirnov & $0,200$. \\
Uji Linearitas & $\begin{array}{l}\text { Deviation from linearity } \\
\text { Independent Samples T Test dan One } \\
\text { Uji homogenitas }\end{array}$ & 0,659 \\
\hline
\end{tabular}

Berdasarkan Tabel 4 diatas dapat dijelaskan bahwa hasil data statistik uji normalitas menggunakan analisis One sample kolmogrov-smirnov menunjukkan bahwa nilai sig uji normalitas sebesar 0,200. Nilai tersebut lebih besar dari 0,05, maka dapat diambil kesimpulan bahwa data dalam penelitian ini berdistribusi normal.

Hasil data statistik uji linearitas menggunakan analisis Deviation from linearity dapat diketahui bahwa nilai signifikansi pada kolom Deviation from Linearity adalah sebesar 0,659. Nilai signifikansi tersebut lebih besar dari 0,05 $(0,659>0,05)$ sehingga dapat dsimpulkan bahwamotivasi belajar siswa memiliki hubungan yang linear dengan kemampuan berpikir 
kreatif IPA materi siklus air siswa kelas V SD N 2 Sengonbugel.

Hasil data statistik uji homogenitas menggunakan analisis Independent Samples T Test dan One Way ANOVA. Nilai signifikansi adalah sebesar 0,807. Hasil tersebut menunjukkan bahwa nilai signifikasi lebih besar dari $0,05(0,807>0,05)$ artinya bahwa nilai pretest dan nilai posttest memiliki varian yang sama (homogeny) pada taraf signifikansi 0,05 .

Hasil analisis korelasi sederhana dapat diketahui bahwa nilai signifikansi sebesar 0,008. Nilai tersebut lebih kecil dari 0,05 $(0,008<0,05)$, jadi Ho ditolak dan Ha diterima. Maka dapat disimpulkan bahwa ada hubungan antara motivasi belajar dengan kemampuan berpikir kreatif IPA materi siklus air siswa kelas V SD N 2 Sengonbugel.

Untuk mengetahui bagaimana pengaruh variabel independen terhadap variabel dependen adalah dengan cara membandingkan antara nilai ti hitung dengan nilai t tabel. Tabel distribusi t dicari pada derajat kebebasan (df) n-k-1. (n adalah jumlah sampel dan $\mathrm{k}$ adalah jumlah variabel independen). Sehingga $t$ tabel diperoleh $\mathrm{df}=(20-1-1=18)$ dengan taraf signifikansi 5\% adalah 2,100. Pengujian menggunakan tingkat signifikansi 0,005 dan 2 sisi. Adapun hasil uji t adalah sebagai berikut.

Tabel 5. Hasil Uji t (parsial)

\begin{tabular}{ccccc}
\hline Variabel & t-hitung & Tabel & Sig. & Keterangan \\
\hline Motivasi Belajar $(\mathrm{X})$ & 3,004 & 2,100 & 0,008 & Berpengaruh dan Signifikan
\end{tabular}

Sumber: Data primer yang diolah, 2021

Berdasarkan Tabel 5. dapat diketahui bahwa hasil pengujian statistik pengaruh motivasi belajar terhadap kemampuan berpikir kreatif menunjukkan nilai thitung sebesar 3,004 dengan nilai t tabel 2,100 dan nilai signifikansi 0,005. Dapat disimpulkan bahwa nilai $t$ hitung lebih besar dari nilai t tabel $(3,004>2,100)$, maka H0 ditolak dan H1 diterima (terdapat pengaruh dan signifikan). Jadi motivasi belajar merupakan variabel bebas yang berpengaruh secara positif dan signifikan terhadap kemampuan berpikir kreatif IPA materi siklus air siswa kelas V SD N 2 Sengonbugel.

Hasil koefisien determinasi $\left(\mathrm{R}^{2}\right)$ digunakan untuk mengukur seberapa jauh kemampuan model dalam menerangkan variasi variable dependent. Dapat diketahui bahwa nilai $R$ Square adalah 0,334. kemudian dapat dijelaskan bahwa sumbangan pengaruh variabel motivasi belajar (X) terhadap kemampuan berpikir kreatif (Y) dipengaruhi sebesar 33,4\%. Jadi besarnya pengaruh antara motivasi belajar (X) terhadap kemampuan berpikir kreatif (Y) adalah sebesar $33,4 \%$ sedangkan sisanya $(100 \%-33,4 \%=66,6 \%)$ dipengaruhi oleh variabel lain diluar penelitian. 
hasil penelitian pengaruh motivasi belajar siswa terhadap keterampilan berpikir kreatif siswa kelas V SDN 2 Sengonbugel. Hasil tersebut memberikan bukti empiris bahwa motivasi belajar berpengaruh positif dan signifikan terhadap kemampuan berpikir kreatif siswa. Hasil penelitian ini juga mendukung penelitian sebelumnya yang dilakukan oleh Shufani (2020) yang memberikan hasil bahwa terdapat pengaruh yang signifikan antara kreativitas terhadap keterampilan berpikir kreatif siswa dengan kontribusi sebesar 41,4\%, terdapat pengaruh yang signifikan antara motivasi belajar terhadap siswa. kemampuan berpikir kreatif dengan sumbangan sebesar 54,4\%, dan kreativitas berpengaruh signifikan terhadap motivasi belajar siswa dengan sumbangan sebesar 60\%. Jika nilai kreativitas dan motivasi belajar meningkat maka kemampuan berpikir kreatif siswa juga meningkat..

\section{Kesimpulan}

Penelitian ini bertujuan untuk mengetahui bagaimana pengaruh dan seberapa besar pengaruh motivasi belajar siswa terhadap kemampuan berpikir kreatif siswa kelas V di SDN 2 Sengonbugel. Berdasarkan hasil penelitian yang telah dilakukan, maka dapat ditarik kesimpulan sebagai berikut:

1. Motivasi belajar berpengaruh secara positif dan signifikan terhadap kemampuan berpikir kreatif siswa kelas V SD N 2 Sengonbugel.

2. Motivasi belajar memberikan kontribusi terhadap kemampuan berpikir kreatif sebesar $33,4 \%$ sedangkan sisanya $(100 \%-33,4 \%=66,6 \%)$ dipengaruhi oleh variabel lain diluar penelitian.

\section{DAFTAR PUSTAKA}

Ahmad, Susanto. (2016). Teori Belajar dan Pembelajaran di Sekolah Dasar.Jakarta: Prenadamedia Group.

Peraturan Menteri Pendidikan Nasional Nomor: 23 Tahun 2016 tentang standar kompetensi kelompok mata pelajaran IPA dan teknologi pada tingkat sekolah dasar.

Pendidikan dan Kebudayaan Nomor: 36962/MPK.A/HK/2020 tentang belajar harus dilakukan dari jarak jauh agar Virus Corona Penyakit (Covid-19).

Kumala, Farida Nur. (2016). Pembelajaran IPA SD. Malang: Ediide Infografika.

Ramadhani, Dini dan Nuryanis. (2017). Analisis kemampuan berpikir kreatif Matematis siswa SD Dalam Menyelesaikan Open-Ended Problem. Jurnal JPSD,4 (2). 55-62.

Yulia Hamda, M. R. (2017). Keterampilan Berpikir Kreatif Pada Siswa Sekolah Menengah di Palangka Raya Menggunakan Pendekatan Saintifik. Jurnal Pendidikan Fisika dan 
Keilmuan (JPFK), (1): 50.

Tina, Wa Ode. (2020). Pengaruh motivasi belajar siswa terhadap berpikir kreatif pada mata materi aplikasi operasi himpunan kelas VII SMP Muhammadiyah Ambon. (Skripsi). Program Studi Pendidikan Matematika Fakultas Ilmu Tarbiyah Dan Keguruan Institut Agama Islam Negeri (IAIN).

Arikunto, S. (2013). Prosedur Penelitian: Suatu Pendekatan Praktik. Jakarta: Rineka Cipta.

Sugiyono. (2016). Metode Penelitian Pendidikan. Bandung: Alfabeta.

Fadilah, A.,Gardijto \& Jadion.(2016). Analisis Kemampuan Berpikir Kreatif Siswa.Fakultas Keguruan Dan Ilmu Pendidikan. Universitas Jambi: Jambi.

Shufani, Ishlakh Nur (2019). Pengaruh Kreativitas dan Motivasi Belajar Terhadap Hasil Belajar Seni Rupa Siswa kelas IV SD-Dabin I Kecamatan Tegal Selatan Kota Tegal. (Skripsi). Universitas Negeri Semarang.

Sardiman,A.M. (2015). Interaksi dan Motivasi Belajar Mengajar. Jakarta: Grafindo. Vol.3 .No.1. 73-82.

Priyatno. Duwi. (2018). SPSS Panduan Mudah Olah Data Bagi Mahasiswa \& Umum. Bandung: CV.Alfabeta. 